\title{
ANALISIS EFEKTIFITAS PENCAIRAN TUNGGAKAN PAJAK DAN PENERIMAAN PAJAK DI KANTOR PELAYANAN PAJAK PRATAMA MEDAN KOTA
}

\author{
Ester Hervina Sihombing, Dede Novitri \\ Politeknik Unggul LP3M Medan \\ Jl.Iskandar Muda No.3 EF Medan-Sumatera Utara \\ www.politeknikunggul.ac.id, info@politeknikunggul.ac.id, estersih
}

\begin{abstract}
Abstrak
Pemerintah mengupayakan sumber penerimaan terutama dari sektor fiskal sebagai salah satu sumber penerimaan negara yang berpotensial paling besar. Baik dari segi penerimaannya maupun segi beberapa banyak pencairan tunggakan pajaknya. Pajak merupakan salah satu iuran wajib masyakat dengan menyerahkan sebagaian dari kekayaannya kepada kas Negara yang disebabkan oleh suatu keadaan, kejadian maupun perbuatan yang memberikan kedudukan tertentu sesuai peraturan yang diterapkan pemerintah dan dapat dipaksakan, akan tetapi tidak ada jasa timbal balik dari pemerintah secara langsung. Namun karena keterbatasan pengetahuan tentang peraturan perpajakan masyarakat mengakibatkan semakin meningkatnya jumlah wajib pajak yang belum melunasi pajak sesuai dengan jangka waktunya, serta jumlah tunggakan pajak yang tidak seimbang dengan pembayarannya. Sistem penagihan yang masih memiliki hambatan menimbulkan semakin meningkatnya tunggakan pajak.

Penelitian ini menilai efektifitas pencairan tunggakan pajak dan penerimaan pajak yang tercermin dalam perkembangan dari rencana dan realisasi pungutan pajak oleh kantor Pelayanan Pajak Pratama Medan Kota pada tahun 2010 sampai dengan 2014. Alat analisis yang digunakan oleh penelitian ini adalah analisis efektifitas pencairan tunggakan pajak dan analisis efektivitas penerimaan pajak pada tahun 2010 - 2014. Sehingga dengan menggunakan alat analisis keefektifan tersebut maka penulis dapat menyimpulkan seberapa besar presentasi efektivitas tunggakan pajak dan penerimaan pajak setiap tahunnya di kantor Penerimaan Pajak Pratama Medan Kota.
\end{abstract}

Kata Kunci: Efektivitas, pencairan tunggakan pajak, Penerimaan pajak

\section{PENDAHULUAN}

\subsection{Latar Belakang}

Efektifitas merupakan keadaan suatu keberhasilan tentang usaha ataupun tindakan untuk mencapai satu tujuan. Untuk mengetahui sesuatu efektif harus diperlukan suatu indikator sebagai tolak ukur untuk mengetahui tingkat keefektifannya.

Dalam perpajakan indikator efektifitas adalah persentase antara hasil pemungutan pajak dengan rencana/potensi pajak, dengan anggapan bahwa semua Wajib Pajak dapat membayar semua pajak terutang. Keefektifan terdiri dari semua tahapan dalam proses penagihan pajak yang telah dilakukan sesuai dengan prosedur yang telah ditetapkan, menentukan Wajib Pajak, memungut pajak, serta menegakkan sistem perpajakan 
sesuai dengan peraturan perundangundangan perpajakan.

Pajak yang terutang oleh Wajib Pajak harus dibayar atau dilunasi tepat pada waktunya. Maka untuk memperingan Wajib Pajak pembayaran pajak dapat diangsur selama satu tahun berjalan, setelah jumlah pajak sesungguhnya terutang diketahui. Oleh karena itu, apabila setelah tanggal jatuh tempo pajak tersebut belum dilunasi maka hal inilah yang mengakibatkan timbulnya tunggakan pajak. Hal ini dapat dilihat dari tunggakan pajak Wajib Pajak di wilayah Sumatera Utara I yang meliputi Medan, Binjai, dan Langkat telah mencapai Rp. 56,8 Milliar. Kondisi tersebut menyebabkan pihak Direktorat Jenderal Pajak Kanwil Sumut I menerapkan upaya paksa dalam memungut tunggakan pajak. Menurut Kepala Kantor Direktorat Jenderal Pajak Sumut I, Ramram Brahmana (Medan Bisnis: 16/8/07), upaya paksa itu menjadi jalan akhir bila himbauan pembayaran pajak pada periode Juni 2007 kepada Wajib Pajak tidak membuahkan hasil. Menurut Ramram (Medan Bisnis: 16/8/07) upaya paksa terhadap Wajib Pajak bisa memacu pertumbuhan pajak sebesar $24,49 \%$ per bulan dari sektor Pajak Bumi dan Bangunan, Pajak Bea Perolehan Hak atas Tanah dan Bangunan, Pajak Penghasilan Orang Pribadi di Sumatera Utara. Hal ini mengingat potensi pajak dari ketiga sektor di Sumatera Utara tersebut masih terbuka lebar. Pajak Penghasilan Orang Pribadi tahun 2007 di Sumatera Utara mencapai Rp. 1.14 Juta Kepala Keluarga dari jumlah itu baru sekitar 250.889 Kepala Keluarga yang tergarap, sehingga masih ada 889.889 Kepala Keluarga lagi yang belum membayar pajak. Dari jumlah Wajib Pajak Orang Pribadi yang belum tergarap ini, Ramram (Medan Bisnis:16/8/07) menargetkan pencapaian sebesar $50 \%$ atau setara dengan 444,5 ribu sampai akhir 2007. Untuk perolehan Pajak Bumi dan Bangunan dan Bea Perolehan Hak atas Tanah dan Bangunan Sumatera Utara 2007 sebesar 1,24 Trilliun. Ramram berharap targetnya bisa dipenuhi. Alasannya, perolehan Pajak Bumi dan Bangunan dan Bea Perolehan Hak atas Tanah dan Bangunan Sumatera Utara dalam dua tahun terakhir juga meningkat cukup signifikan, yakni 2005 sebesar 720,79 Milliar dan 2006 sebesar 895,59 Milliar.

Penerimaan pajak merupakan salah satu sumber terbesar dan saat ini telah mencapai $80 \%$ dari penerimaan negara. Direktorat Jenderal Pajak sebagai bagian dari Kementrian Keuangan Republik Indonesia mempunyai tanggung jawab untuk menarik pajak dari masyarakat.

Belakangan ini masyarakat lebih kritis dan berani dalam menyuarakan keinginannya akan pelayanan yang baik, khususnya pelayanan publik yang diberikan oleh pemerintah. Seiring dengan bertambahnya beban yang harus di tanggung masyarakat, bertambah pula tuntutan masyarakat akan tersedia pelayanan publik yang berkualitas tinggi. Namun krisis finansial global tampaknya tidak berdampak buruk terhadap kinerja penghimpun pajak di lingkungan Direktorat Jenderal Pajak Kanwil Sumut I pada periode Jan-Okt 2009. Sebab realisasi penerimaan selama 10 bulan tahun 2009 sudah mencapai $88,21 \%$ atau sekitar 5,91 Trilliun dari total rencana penerimaan sebesar 6,7 
Trilliun. Realisasi pencapaian penerimaan tersebut meningkat sekitar $12,45 \%$ dibanding kinerja penghimpun pajak pada periode yang sama tahun 2008. Kinerja tersebut disampaikan oleh Kepala Kantor Wilayah Direktorat Jenderal Pajak Sumut I Medan Yusri Natar Nasution kepada Medan Bisnis melalui Kepala Bidang Penyuluhan Pelayanan dan Hubungan Masyarakat (Kabid P2 dan Humas) Christofer Hutapea di Gedung Keuangan Negara (GKN) Medan Jl Diponegoro Medan, Rabu (4/11/09). Perinciannya realisasi penerimaan Pajak Penghasilan mencapai $77,43 \%$ dari rencana penerimaan sebesar Rp. 4,8 Trilliun. Penerimaan Pajak Penghasilan periode Jan-Okt 2009 menurut Hutapea (Medan Bisnis: 5/11/09) meningkat mencapai $19,45 \%$ dibanding realisasi pada periode yang sama tahun 2008. Kemudian PPN dan rencana penerimaan 1.1 Trilliun bahkan bisa dilampaui yakni terhimpun senilai 1,3 Trilliun atau $120,8 \%$. Jenis pajak lain yang menopang penerimaan kanwil Direktorat Jenderal Pajak Sumut I adalah pajak lainnya yang penghimpunannya sudah berkisar 71,7\% atau sekitar Rp. 57 Milliar dari rencana penerimaan Rp. 80 Milliar. Sedangkan realisasi PBB hingga Oktober 2009 mencapai $89,62 \%$ dari rencana penerimaan sebaesar 690 Milliar atau meningkat sebesar 27,72\% dibandingkan pencapaian penerimaan pajak pada periode yang serupa tahun 2008. Salah satu upaya yang dilakukan pihak Direktorat Jenderal Pajak Kanwil Sumut I untuk mewujudkan rencana penerimaan tersebut adalah membuat himbauan tertulis kepada Wajib Pajak yang sudah disampaikan melalui Kantor Pelayanan Pajak
Pratama maupun Kantor Pelayanan Pajak Madya yang ada di lingkungan Kanwil Direktorat Jenderal Pajak Sumut I.

Kantor Pelayanan Pajak Pratama Medan Kota merupakan salah satu unsur pelaksana kegiatan operasional pemberian pelayanan di lingkungan Direktorat Jenderal Pajak Kanwil Sumut I. Unsur pelaksana tersebut merupakan Unit Esselon III yang di pimpin oleh kepala kantor dan bertanggung jawab kepada kepala kantor wilayah Sumut I yang bertugas menghimpun penerimaan negara dari sektor pajak. Kantor Pelayanan Pajak Pratama Medan Kota dalam melakukan kegiatan operasional yang bergerak di bidang Pajak Penghasilan (PPh), Pajak Pertambahan Nilai (PPN), Pajak Penjualan atas Barang Mewah (PPnBM), pajak tidak langsung lainnya dalam daerah wewenangnya berdasarkan kebijaksanaan teknis yang di tetapkan Direktorat Jenderal Pajak. Minimnya tingkat kepatuhan Wajib Pajak Sumut I mengakibatkan timbulnya tunggakan pajak. Memperkerjakan karyawan di hari sabtu untuk melayani Wajib Pajak ternyata tidak membuat tingkat kepatuhan Wajib Pajak di Sumut meningkat. Berdasarkan informasi yang didapatkan dari Kepala KPP Pratama Medan Kota Yan Santoso (Harian Seputar Indonesia 3/4/012), khususnya pada KPP Pratama Medan Kota, Surat Pemberitahuan Tahunan yang masuk hingga 31 maret di loket Medan Kota hanya sebanyak 29.000 orang. Jumlah tersebut tidak mencapai setengah dari Wajib Pajak di medan kota sebanyak 87.000 orang. Akibat dari jumlah Wajib Pajak yang tidak patuh menyebabkan jumlah tunggakan pajak dengan pencairan atau pembayaran yang 
memungkinkan dari tahun ke tahun semakin meningkat.

Berdasarkan uraian yang telah dikemukakan diatas, maka penulis tertarik ingin mengetahui keefektifan dari rincian pencairan tunggakan pajak beserta penerimaan pajak yang dihitung dari tahun ke tahun dengan mengambil judul "Analisis Efektifitas Pencairan Tunggakan Pajak dan Penerimaan Pajak di Kantor Pelayanan Pajak Pratama Medan Kota"

\subsection{Perumusan Masalah}

Berpedoman kepada latar belakang pemilihan judul diatas, pembahasan ini difokuskan pada halhal berikut :

1. Bagaimanakah efektifitas pencairan tunggakan pajak di KPP Medan Kota di Kantor Pelayanan Pajak Medan Kota pada tahun 2010 sampai dengan 2014.?

2. Bagaimanakan efektifitas penerimaan pajak di KPP Medan Kota di Kantor Pelayanan Pajak Medan Kota pada tahun 2010 sampai dengan 2014.?

3. Apa saja hambatanhambatan yang terjadi selama pelaksanaan pencairan tunggakan pajak ?

4. Apa saja upaya-upaya yang telah dilakukan KPP Medan Kota dalam pencairan tunggakan pajak?

\subsection{Tujuan Penelitian}

Tujuan yang diinginkan dalam penulisan ini yakni :

1. Menganalisis efektifitas dalam pencairan tunggakan pajak dan penerimaan pajak pada KPP Medan Kota

2. Meninjau kembali masalahmasalah yang menjadi hambatan dalam pencairan tunggakan pajak

3. Mengetahui upaya-upaya yang dilakukan dalam pencairan tunggakan pajak pada KPP Medan Kota.

\subsection{Manfaat Penulisan}

Ada beberapa manfaat yang diambil dalam penelitian ini antara lain :
1. Untuk menganalisis efektifitas pencairan tunggakan pajak dan penerimaan pajak di kantor pelayanan pajak pratama medan kota"

2. Penelitian ini bisa digunakan sebagai tambahan sumber informasi bagi pihak kantor pelayanan pajak pratama medan kota khususnya dan masyarakat umumnya.

\section{METODE PENELITIAN}

\subsection{Ruang Lingkup Penelitian}

Ruang lingkup penelitian ini meliputi : Analisis efektifitas pencairan tunggakan pajak dan penerimaan pajak di kantor pelayanan pajak pratama medan kota yang akan membawa kepada hasil penerimaan pajak yang maksimal.

\subsection{Jenis dan Sumber Data}

\subsubsection{Jenis Data}

Jenis data yang digunakan penulis pada penelitian ini adalah : 
a. Data Kualitatif yaitu data dalam bentuk kata, kalimat ataupun gambar.

b. Data Kuantitatif yaitu data dalam bentuk angka atau data kuantitatif yang diangkakan.

\subsubsection{Sumber Data}

Sumber data berasal dari :

a. Data Primer, yaitu data yang diperoleh langsung dari objek yang diteliti mengenai datadata yang berhubungan langsung dengan peneliti, total dari rencana dan realisasi tunggakan pajak dan penerimaan pajak 2010 sampai dengan 2014 di Kantor Pelayanan Pajak Medan Kota.

b. Data sekunder, yaitu data yang diperoleh secara tidak langsung dengan mempelajari buku-buku, literature, makalah, serta UndangUndang Perpajakan yang berlaku.

\subsection{Teknik Pengumpulan Data}

Teknik pengumpulan data adalah cara mendapatkan informasi selengkap-lengkapnya dari narasumber atau reponden. Teknik yang tepat akan mengefektifkan pengumpulan data, serta cara terbaik mendapatkan data yang akurat dan maksimal. Untuk melengkapi data yang diperlukan maka Penulis menggunakan alat/instrumen penelitian yaitu:

1. Observasi (Pengamatan) Observasi merupakan pengamatan yang meliputi pemusatan perhatian terhadap suatu objek yang dilakukan dengan cara melihat secara langsung kepada kegiatan dari objek kantor tersebut dengan cara memantau aktifitas-aktifitas yang dilakukan customer services di PT. Fajar Insan Nusantara Medan

2. Interview (wawancara)

Peneliti langsung mengadakan tanya jawab dengan pihak-pihak yang berkompeten langsung dengan penelitian untuk mendapatkan data-data yang penulis perlukan.

3. Studi Dokumen

Yaitu penelitian yang dilakukan dengan mengunakan dokumen dan bahan literatur lainnya sesuai dengan pembahasan penelitian penulis sebagai bahan rujukan dan pertimbangan.

\subsection{Teknik Analisis Data}

Metode analisa data yang dipergunakan dalam penulisan ini adalah : Metode deskriptif, yaitu suatu metode dimana data yang telah diproses, disusun, dikelompokkan, dianalisis, kemudian diinterpretasikan sehingga diperoleh gambaran tentang masalah yang dihadapi dan untuk menjelaskan hasil perhitungan. Data diperoleh dari data primer dan data sekunder dari tahun 2010 sampai dengan tahun 2014.

\section{HASIL PEMBAHASAN}

\subsection{Efektifitas \\ Pencairan Tunggakan di KPP Medan Kota}

Efektifitas pencairan tunggakan pajak dengan mengaju pada Total dari tunggakan pajak dengan rencana/target dan realisasi pencairan 
tunggakan untuk pada tahun 2010, 2011, 2012, 2013, dan 2014.

Perkembangan tunggakan pajak dapat dihitung dengan menggunakan rumus, sebagai berikut

Total Realisasi Pencairan Tunggakan Pajak * $100 \%$

Total Rencana Pencairan Tunggakan Pajak

Dari rumus tersebut dapat dihitung keefektifan perkembangan tunggakan pajak dari data tunggakan pajak tahun 2010 sampai dengan tahun 2014. penerimaaan pajak. Bentuk kegiatannya adalah penggalian potensi. Penggalian potensi pajak terdiri dari pemetaan (mapping), kegiatan mengumpulkan data dan informasi misalnya jenis usaha, proses bisnis, laporan keuangan (profiling), penilaian kewajaran kinerja keuangan (benchmarking).

Pada data tunggakan pajak pada tahun 2010 penulis terbatas tidak mendapatkan data dikarenakan oleh beberapa hal yaitu yang pertama fiskus tidak memiliki pertinggal data akumulasi tunggakan pada tahun 2010 karena sudah diserahkan kepada Kanwil Direktorat Jenderal Pajak Sumut I, yang kedua adanya mutasi atau pemindahahan pegawai pada bagian seksi penagihan, maka keadaan komputer benar-benar bersih dan tidak terdapat pertinggal Sumber : Seksi Penagihan

\begin{tabular}{|c|c|c|c|c|}
\hline Thn & $\begin{array}{l}\text { Tunggakan Awal } \\
\text { (a) }\end{array}$ & $\begin{array}{c}\text { Penambahan } \\
\text { Tunggakan } \\
\text { (extraeffort) } \\
\text { (b) }\end{array}$ & $\begin{array}{l}\mathrm{Re} \\
\text { alisasi } \\
\text { (c) }\end{array}$ & $\begin{array}{c}\text { Sisa } \\
(a+b-c)\end{array}$ \\
\hline 2010 & & & & \\
\hline 2011 & 95.449 .650 .016 & 0 & 2.760 .030 .500 & 92.389 .619 .516 \\
\hline 2012 & 87.353 .893 .940 & 30.670 .844 .052 & 2.887 .082 .357 & 115.137 .655 .635 \\
\hline 2013 & 99.383 .528 .292 & 5.610 .607 .315 & 3.652 .990 .866 & 101.341 .144 .741 \\
\hline 2014 & 123.152 .798 .080 & 13.874 .632 .352 & 10.771 .507 .020 & 126.255 .923 .412 \\
\hline
\end{tabular}

Tabel 3.1 Perkembangan Tunggakan Pajak KPP Medan Kota

yang dilakukan dalam upaya pencairan tunggakan pajak untuk meningkatkan jumlah penerimaan. Pada Tabel 3.1 terdapat extraeffort (penambahan tunggakan). Adapun pengertian dari extraeffort adalah usaha extra untuk mencari penerimaan pajak diluar penerimaan pajak rutin agar tercapai target data softcopy oleh fiskus yang sebelumnya.

Tingkat keefektifan pada tahun 2011 dapat dilihat dari segi realisasi/pembayaran tunggakan pajak sebesar Rp. 2.760.030.500 dengan total tunggakan awalsebesar Rp. 95.449.650.016 dan tidak adanya extraeffort (penambahan tunggakan) 3.6jan memperoleh tingkat keefektifan yang termasuk dalam kategori tidak 8.87 $\mathrm{ektif}$ yaitu $2,89 \%$.

Tingkat keefektifan pencairan tunggakan pada tahun 2012 dapat dilihat dari segi realisasi tunggakan pajak yaitu $3,30 \%$ dan termasuk tidak efektif, akan tetapi tahun 2012 mempunyai extraeffort (penambahan tunggakan) sebesar Rp. 30.670.844.052 mengakibatkan bertambahnya tunggakan awal sebesar Rp.87.353.893.940 menjadi Rp. 118.024.737.992, hal ini dapat dikatakan juga tidak efektif karena meningkatnya tunggakan pajak tahun 2012 dari tahun sebelumnya tetapi 
tidak disertai pula dengan jumlah realisasi tunggakan pajak yang mendukung.

Keefektifan pencairan tunggakan pajak pada tahun 2013 jika dilihat dari segi realisasi tunggakan pajak yaitu $3,67 \%$ dan termasuk tidak efektif, akan tetapi tahun 2013 juga mempunyai extraeffort (penambahan tunggakan) sebesar Rp. $\quad$ 5.610.607.315 mengakibatkan bertambahnya tunggakan awal sebesar Rp. 99.383.528.292 menjadi Rp. 104.994.135.607. Hal ini juga dapat dikatakan tidak efektif karena meningkatnya total tunggakan pajak tahun 2013 dari tahun sebelumnya tetapi tidak disertai dengan jumlah realisasi yang mendukung walaupun realisasi yang diterima juga meningkat dari tahun sebelumnya. Keefektifan pencairan tunggakan pajak tahun 2014jika dilihat dari segi realisasi tunggakan pajak diperoleh sebesar $8,87 \%$. Walaupun mengalami kenaikan yang cukup bagus dari tahun sebelumnya tetapi tingkat keefektifannya masih kurang efektif. Total tunggakan tahun 2014 juga mengalami peningkatan yang pesat yang disebabkan adanya extraeffort sebesar Rp. 13.874.632.352 menambah tunggakan awal sebesar Rp. 123.152.798.080 menjadi Rp. 137.027.430.432. Hal ini juga dapat dikatakan tidak efektif karena meningkatnya total tunggakan pajak tahun 2014 dari tahun sebelumnya tetapi tidak disertai dengan jumlah realisasi yang diperoleh pada tahun tersebut walaupun realisasi yang diperoleh mengalami peningkatan dari tahun sebelumnya.

Dari penjelasan data tunggakan di atas, dapat dikatakan bahwa perbandingan realisasi tunggakan pajak dan total tunggakan pajak setiap tahun pada KPP Pratama Medan Kota adalah berbanding tegak lurus, meskipun realisasinya mengalami peningkatan selama lima tahun terakhir tetapi total tunggakan pajaknya juga meningkat, hal ini dikarenakan adanya penggalian potensi penerimaan pajak (extraeffort). Maka kesimpulan dari tabel 4.1 tentang data tunggakan pajak di KPP Pratama Medan Kota bahwa tingkat pencairan tunggakan pajak secara keseluruhannya adalah masih kurang efektif.

\subsection{Efektifitas Penerimaan Pajak di KPP Medan Kota}

Efektifitas penerimaan pajak di KPP Medan Kota dapat dihitung dengan menggunakan rumus :

Total Realisasi Penerimaan Pajak* $100 \%$

Total Rencana Penerimaan Pajak

Berikut tabel 3.2 mengenai penerimaan pajak terhadap perencanaan pajak dan realisasinya dan sebagian berasal dari pencairan tunggakan pajak.

Sumber: Seksi Pengolahan Data dan Informasi

\begin{tabular}{|c|c|c|c|}
\hline \multirow{2}{*}{ Tahun } & Target & Realisasi & $\%$ \\
& & & \\
\hline 2010 & 399.979 .000 .000 & 444.979 .000 .000 & 111.25 \\
\hline 2011 & 478.850 .000 .000 & 517.711 .000 .000 & 108.11 \\
\hline 2012 & 600.484 .000 .000 & 610.944 .000 .000 & 101.75 \\
\hline 2013 & 809.089 .000 .000 & 797.118 .000 .000 & 98.5 \\
\hline 2014 & 930.460 .000 .000 & 916.391 .000 .000 & 98.48 \\
\hline
\end{tabular}

Tabel 3.2 Penerimaan Pajak KPP Medan Kota

Dari Tabel 3.2 atas data penerimaan pajak di KPP Pratama Medan Kota dapat dilihat dimulai dari tahun 2010 tingkat keefektifan penerimaan pajak tahun 2010 sangat efektif sebesar $111,25 \%$ dengan targer penerimaan sebesar Rp. 399.979.000.000 dengan realisasi sebesar Rp. 444.979.000.000. Pada 
tahun 2011 tingkat keefektifan penerimaan pajak dengan target penerimaan pajak yang meningkat dari tahun sebelumnya sebesar Rp. 478.850.000.000 dan realisasi penerimaan pajak yang juga meningkat sebesar Rp. 517.711.000.000, dengan memperoleh persentase keefektifan yang menurun dari tahun sebelumnya sebesar 108,11\% masih termasuk dalam kategori sangat efektif.

Pada tahun 2012 tingkat keefektifan penerimaan pajak menurun dari tahun sebelumnya sebesar $101,75 \%$ kategori sangat efektif, dengan target penerimaan pajak yang meningkat dari tahun sebelumnya sebesar Rp. 600.484.000.000 dan realisasi penerimaan pajak yang meningkat dari tahun sebelumnya sebesar $\mathrm{Rp}$. 610.944.000.000.

Pada tahun 2013 tingkat penerimaan pajak menurun juga dari tahun sebelumnya sebesar $98.5 \%$ akan tetapi masih tergolong efektif dengan target penerimaan pajak yang meningkat dari tahun sebelumnya sebesar Rp. 809.089.000.000 dan realisasi penerimaan pajak yang diperoleh meningkat sebesar Rp. 797.118.000.000. Keefektifan penerimaan pajak tahun 2014 dengan penerimaan pajak yang juga memperoleh peningkatan dari tahun sebelumnya sebesar Rp. 930.460.000.000 dan realisasi penerimaan pajak yang juga meningkat dari tahun sebelumnya sebesar Rp. 916.391.000.000, sehingga memperoleh persentase keefektifan yang mengalami penurunan yang sangat tipis dari tahun sebelumnya yaitu $98,48 \%$.

Dari penjelasan diatas dapat dikatakan bahwa penerimaan pajak di KPP Pratama Medan Kota adalah
Perbandingan target penerimaan pajak dan realisasi penerimaan pajak untuk tahun 2010 sampai dengan tahun 2012 mengalami siklus yang sejajar, yang artinya target penerimaan pajak meningkat sejajar dengan realisasi penerimaan pajak yang juga meningkat dari tahun 2010 sampai dengan tahun 2012. Kemudian juga telah memperoleh keefektifan penerimaan pajak untuk tahun 2010 sampai dengan 2012 telah mencapai target bahkan melebihi dari target/rencana penerimaan pajak. Sedangkan untuk tahun 2013 sampai dengan 2014 siklus target penerimaan pajak mengalami peningkatan yang cukup pesat namun disertai dengan realisasi penerimaan pajak yang cukup mendukung walaupun belum mencapai target/rencana penerimaan pajak yang diharapkan. Maka kesimpulan yang dapat penulis ambil tentang keefektifan penerimaan pajak pada data penerimaan pajak di KPP Pratama Medan Kota secara keseluruhan adalah sudah efektif.

\subsection{Hambatan-Hambatan dalam Pelaksanaan Penagihan Tunggakan Pajak di KPP Medan Kota}

Seksi penagihan mempunyai peranan yang sangat penting dalam upaya pencairan tunggakan pajak. Dari waktu ke waktu tunggakan pajak semakin meningkat, dan hal ini harus diimbangi dengan usaha pencairan tunggakan pajak yaitu dengan pelaksanaan tindakan penagihan. Dalam pelaksanaannya tindakan penagihan pajak mempunyai berbagai macam kendala, diantaranya sebagai berikut 
1. Kendala Intern

a. Sumber Daya Manusia

Sumber Daya Manusia adalah orang-orang yang terlibat di dalam organisasi, Sumber Daya Manusia merupakan motor utama dalam suatu organisasi. Dalam setiap organisasi kerja, seluruh aktivitas organisasi mulai dari perencanaan, pelaksanaan, evaluasi dan pengembangan tidak akan terlaksana tanpa melibatkan sumber daya manusia yang memadai jumlahnya dan kompeten. Faktor sumber daya manusia merupakan hal yang sangat berpengaruh dalam pelaksanaan tindakan penagihan pajak. Kondisi sumber daya manusia dalam hal ini Jurusita Pajak dapat dilihat dari dua segi yaitu kualitas dan kuantitas Jurusita Pajak. Kualitas Jurusita Pajak dapat dikatakan baik apabila Jurusita mampu melaksanakan tugas yang diberikan dengan baik dan dengan penuh tanggung jawab dengan waktu kerja yang telah ditentukan. Artinya Jurusita Pajak mampu berfungsi secara penuh dalam pekerjaannya. Kuantitas Jurusita Pajak dapat dikatakan cukup apabila tugas yang diserahkan dapat diselesaikan dengan jumlah Jurusita Pajak yang ada.

b. Penatausahaan Administrasi Seksi Penagihan.
Salah satu faktor yang mempengaruhi keberhasilan seksi penagihan mencapai target pelaksana tindakan penagihan tunggakan pajak dalah bagaimana petugas tata usaha piutang pajak melakukan penatausahaan administrasi penagihan dengan tata tertib dan akurat. Tanpa administrasi yang baik upaya penegakan hukum dapat menjadi terhambat. Salah satu kendala yang dihadapi seksi penagihana KPP Pratama Medan Kota ialah data-data penagihan pajak tahuntahun sebelumnya tidak di administrasikan dengan baik sementara petugas penagihan KPP Medan Kota adalah masih kebanyakan orang baru sehingga sangat sulit dalam melaksanakan tindak lanjut tindakan penagihan.

\section{Kendala Ekstern}

a. Kerjasama dengan lembaga terkait.

Dalam pelaksanaan penagihan pajak seringkalli dijumpai permasalahan tidak ditemukannya penanggung pajak, sehingga wajib pajak berpindah dari tempat asalnya dan penanggung pajak tidak memberitahukan mengenai kepindahan alamatnya dan/atau data penanggung pajak yang tidak mutakhir sehingga nama dan/atau alamat penanggung pajak yang tercantum dalam surat paksa maupun surat perintah melaksanakan penyitaan sudah tidak dapat ditemukan lagi.

Masalah ini seringkali dialami oleh jurusita dalam mengindikasikan penanggung pajak sehingga 
mempersulit pelaksanaan tugas Jurusita Pajak. Dalam hal ini adanya peningkatan kerjasama dengan pihak lain seperti instansi pemerintah dan lembaga-lembaga swasta terkait merupakan hal yang sangat penting, karena wajib pajak/penanggung pajak dalam menjalankan usaha dan kegiatannya tentu tidak terlepas dari hubungan dengan pihak-pihak tersebut. Dalam proses penagihan pajak, jurusita pajak selain menghadirkan saksi juga dapat meminta bantuan pihak ketiga untuk memperlancar proses penagihan tersebut, namun kenyataan yang dihadapi di lapangan pihak ketiga ternyata belum mengetahui dengan baik ketentuan perundang-undangan yang berlaku.

Berikut beberapa hambatan yang berasal dari pihak ketiga :

1. Pihak bank.

Pihak bank seringkali tidak kooperatif dengan merahasiakan keterangan mengenai nasabahnya yang akan diperiksa untuk kepentingan perpajakan, salah satunya pada saat proses penyitaan.

2. Pihak instansi pemerintah.

Yang dimaksud aparat pemerintah daerah di sini adalah termasuk juga petugas kelurahan setempat atau aparat pemerintah daerah unit lain yang bertugas di wilayah tempat berlangsungnya penyitaan. Salah satu contohnya adalah keengganan petugas kelurahan setempat untuk dimintakan bantuannya menjadi saksi dalam hal penyitaan tidak dihadiri oleh wajib pajak.

3. Pihak lain, seperti Dinas Perhubungan.

Sehubungan pelaksanaan lelang, pihak KPP diharuskan untuk meminta informasi harga atas barang tertentu, misalnya harga kendaraan yang akan digunakan sebagai bahan pertimbangan penentuan limit harga terhadap barang yang akan dilelang. Namun, seringkali permintaan tersebut diperoleh dalam waktu yang agak lama sehingga dapat menghambat pelaksanaan lelang.

4. Pengetahuan Wajib Pajak Banyak wajib pajak yang beranggapan bahwa apabila tidak ada kegiatan usaha, maka wajib pajak tersebut tidak perlu melaporkan kewajiban perpajakannya setiap bulan ke KPP, akibatnya wajib pajak dikenakan sanksi administrasi karena tidak melaporkan kewajiban perpajakannya tersebut dan akhirnya menjadi tunggakan pajak bagi KPP Medan Kota. Wajib pajak kadangkala salah dalam mengartikan masalah pengajuan keberatan karena kurangnya pengetahuan tentang peraturan perpajakan.

Pada umumnya wajib pajak beranggapan bahwa pengajuan keberatan yang sedang dilakukannya dapat menunda kewajiban membayar pajak dan pelaksanaan penagihan pajak. Hal ini tentunya akan menyebabkan terhambatnya pencairan tunggakan pajak. Tindakan persuasif dengan sosialisasi kepada wajib pajak/penanggung pajak merupakan tindakan sangat penting untuk masing-masing pihak mengetahui hak dan kewajiban perpajakannya sehingga tidak menghambat pelaksanaan tindakan penagihan pajak.

5. Wajib Pajak Sudah Tidak Berada di Alamat Terdaftar.

$\begin{array}{ccc}\text { Salah } & \text { satu unsur yang } \\ \text { membuat } & \text { proses } & \text { pencairan }\end{array}$ tunggakan pajak berhasil adalah adanya kejelasan alamat tempat tinggal dan tempat usaha wajib pajak. Tanpa alamat yang jelas sudah pasti menyulitkan petugas pajak 
untuk melakukan pengecekan ulang atas pelaksanaan kewajiban perpajakannya.

Kendala yang terjadi dalam rangka pencairan tunggakan pajak untuk tahun 2010 sampai dengan 2011 tersebut karena hal-hal sebagai berikut:

- Ketidaksesuaian data identitas wajib pajak/penanggung pajak dengan kondisi yang ada dilapangan.

Dalam arti wajib pajak/penanggung pajak mengganti identitasnya atau mengganti nama dari Kartu Tanda Penduduk (KTP) agar bisa terhindar dari kewajiban perpajakannya.

- Adanya kesulitan dalam mencari kesesuaian antara jumlah utang pajak dengan nilai objek sita yang dimiliki wajib pajak/penanggung pajak.

Wajib pajak tidak ditemukan lagi alamatnya karena berpindah-pindah atau ganti kepemilikan usaha.

- Objek sita tidak ada karena telah dijadikan jaminan kepada pihak kreditor/bank

- Ketidakmampuan wajib pajak untuk membayar tunggakan pajak karena wajib pajak yang bersangkutan tidak mempunyai usaha lagi atau wajib pajak orang pribadi yang bersangkutan sudah meninggalkan Indonesia untuk jangka waktu yang tidak dapat dipastikan.

- Wajib pajak tidak mengetahui adanya tunggakan pajak sebagai akibat dari ketidaktahuan wajib pajak tentang kewajiban perpajakannya.

- Kesadaran Wajib Pajak. Kesadaran wajib pajak memenuhi kewajiban perpajakan di sebagian kalangan masih sangat rendah, adanya wajib pajak yang menghindar dari pembayaran kewajiban pajaknya dengan berbagai alasan, dan panggilan persuatif kepada wajib pajak yang tidak direspon, sehingga pencairan tunggakan pajak terhambat. Hal ini disebabkan oleh rendahnya ketaatan masyarakat terhadap hukum dan kurang mengerti arti dari maksud pembayaran pajak tersebut. Apabila wajib pajak tersebut tidak taat terhadap pembayaran pajak maka akan menimbulkan tingkat pertumbuhan perekonomian semakin rendah/lambat.

- Tindak kekerasan

Adanya perlakuan yang tidak baik atau ancaman fisik penanggung pajak terhadap fiskus di lapangan ketika menjalankan tugasnya.

- Likuiditas

Kesulitan likuiditas merupakan alasan yang seringkali diberikan penanggung pajak saat jurusita pajak akan melakukan tindakan penyitaan terhadap objek sita milik penanggung pajak. Kesulitan likuiditas merupakan masalah yang umum yang dialami oleh suatu kegiatan usaha dan berdampak sangat besar pada kemampuan finansial penanggung pajak. Untuk menghasilkan laba dari produksi untuk masa yang berikutnya pun sulit ditambah dengan tunggakan pajak yang harus dilunasi oleh penanggung pajak. Namun hukum tetap harus tetap ditegakkan dan kewajiban penanggung pajak sudah semestinya dipenuhi dengan baik. Berdasarkan ketentuan UndangUndang Perpajakan No. 16 Tahun 2009 pasal 21 ayat 3a tentang penagihan pajak, dinyatakan bahwa dalam hal 
wajib pajak dinyaitakan pailit, bubar, atau dilikuidasi makan likuidator, atau orang atau badan yang ditugasi untuk melakukan pemberesan dilarang membagikan harta wajib pajak dalam pailit, pembubaran atau likuidasi kepada pemegang saham atau kreditur lainnya sebelum menggunakan harta tersebut untuk membayar utang pajak wajib pajak tersebut. Dengan demikian, wajib pajak yang dinyatakan bubar atau dalam likuidasi oleh pengadilan masih mempunyai kewajiban untuk melunasi utang pajaknya. Akan tetapi, yang sering terjadi adalah apabila wajib pajak dinyatakan bubar atau dilikuidasi, akan sangat sulit bagi petugas atau jurusita pajak untuk menagih tunggakan pajak tersebut.

\section{- Objek Sita}

Faktor yang menjadi kendala bagi jurusita pajak dalam melakukan tindakan penyitaan terhadap harta penanggung pajak terjadi apabila barang yang akan disita itu terlebih dahulu disita oleh pengadilan negeri. Sedangkan pada prinsipnya barang yang telah disita untuk orang lain tidak dapat dilakukan penyitaan. Jika jurusita pajak menemukan barang demikian (telah terlebih dahulu disita), maka cara yang dapat ditempuh adalah jurusita pajak menyerahkan salinan surat paksa sebelum tanggal penjualan barang kepada pengadilan negeri dalam daerah dimana barang itu disita. Dalam hal ini hakim pengadilan negeri yang bersangkutan menentukan cara pembagian hasil penjualan barang antara kantor pajak dengan orang yang berpiutang lainnya yaitu kreditor dari pemilik barang dijual tadi. Apabila terdapat keputusan pengadilan negeri ini ada pihak yang berkeberatan, maka dapat diajukan banding kepada pengadilan tinggi. Demikian pula, petugas pajak sulit mengidentifikasi objek sita yang disebabkan utang pajak wajib pajak yang cukup materil, tetapi wajib pajak tidak memiliki objek sita yang memadai untuk membayar tunggakannya. Pada umumnya dalam menjalankan kegiatan usahanya, penanggung pajak menggunakan sistem sewa dan leasing untuk barang-barang operasional perusahaan seperti gedung, kendaraan, peralatan usaha dan sebagainya. Untuk melakukan penyitaan terhadap sarana usaha penanggung pajak pun menjadi bukan hal yang mudah untuk dilakukan mengingat penyitaan atas barangbarang tersebut dapat menimbulkan dampak yang cukup luas seperti terhentinya kegiatan operasi perusahaan, produksi barang macet, pengangguran muncul dan negara juga dirugikan.

Keberadaan objek sita juga memberikan kendala bagi jurusita pajak dimana objek sita beda diluar wilayah kerja jurusita pajak yang bersangkutan. Dalam KEP.DJP No. KEP-21/PJ/2002 diuraikan secara lengkap mengenai tata cara pemberitahuan pelaksanaan penagihan pajak dengan surat paksa dan penyitaan di luar wilayah kerja pejabat yang berwenang menerbitkan surat paksa, sehingga dalam 
melaksanakan tugasnya Kepala KPP di suatu wilayah kerja dapat meminta bantuan kepada Kepala KPP di wilayah kerja lainnya. Namun untuk melaksanakannya memerlukan waktu yang tidak sedikit mengingat masing-masing KPP memiliki pekerjaan yang juga tidak sedikit untuk diselesaikan.

Barang-barang milik penanggung pajak yang akan disita telah dipindahtanggankan, atau telah dijadikan jaminan tanpa ada pemberitahuan kepada KPP. Hal ini dapat terjadi karena penanggung pajak memang sengaja untuk memindahtangakan/menjaminkan kepada pihak lain dengan harapan barang-barang tersebut dapat dihargai lebih tinggi dibandingkan jika barang tersebut di lelang atau karena penanggung pajak tidak mau terbebani dengan biaya lelang.

Faktor lain saat melakukan tindakan pelelangan seringkali objek sita yang akan dilelang sulit untuk dicarikan pembeli, terutama atas barang-barang sitaan berbentuk barang tidak bergerak seperti tanah dan bangunan yang cukup sulit untuk terjual dengan waktu yang cepat.

\subsection{Upaya-Upaya Penagihan Tunggakan Pajak}

\section{dalam} Pencairan

Ada beberapa upaya yang harus dilakukan untuk mengatasi hambatan hambtan dalam melaksanakan penagihan pencairan tunggakan pajak antara lain :

1. Dalam upaya melaksanakan kegiatan penagihan, jurusita pajak pun sebaiknya lebih gencar melakukan pemblokiran rekening penanggung pajak yang memiliki tunggakan pajak. Dampaknya lebih cepat terlihat dimana penanggung pajak akan segera membayar tunggakan pajaknya setelah dilakukan pemblokiran rekening. Dan ternyata berdasarkan pengalaman jurusita pajak pun dibandingkan menyita aset penanggung pajak yang pelaksanaanya mengalami kesulitan, lebih efektif melakukan pemblokiran rekening penanggung pajak. Hal ini dikarenakan pemblokiran rekening berkaitan erat dengan citra dan kredibilitas penanggung pajak.

2. Meningkatkan penggalangan jaringan kerja (network) atau berkoordinasi dengan lebih baik dengan perangkat pemerintah mulai dari tingkat desa hingga pemerintah daerah maupun dengan instansi lain seperti pajak bumi dan bangunan, bea cukai, badan pertahan nasional, kepolisian, lembaga perbankan dan lembagalembaga swasta agar tim penagihan dapat memiliki banyak bekal untuk melakukan langkah dan meningkatkan kinerjanya, juga memperoleh bantuan dan dukungan dari pihak-pihak tersebut dalam melakukan tindakan penagihan aktif.

3. Meningkatkan penyuluhan kepada wajib pajak mengenai hak dan kewajiban 
kenegaraannya, terlebih khusus mengenai pelunasan tunggakan pajak dengan kemasan yang menarik, seperti pemberian door prize bagi wajib pajak yang dapat menjawab pertanyaan seputar perpajakan atau kerjasama dengan pihak lain seperti media massa melalui talkshow ataupun penayangan iklan perpajakan yang mampu menggugah semangat wajib pajak untuk membayar pajak.

4. Pengadministrasian yang lebih tertib dengan cara penertiban berkas-berkas yang ada di seksi penagihan maupun seksi-seksi terkait lainnya seperti penyampaian dokumen yang lebih teratur, penambahan ruangan untuk menyimpan dokumen apabila ruangan yang ada sudah tidak dapat menampung dokumen yang ada dan pengoptimalan Sistem Informasi Perpajakan (SIP).

5. Jurusita pajak harus terus belajar secara mandiri guna meningkatkan

keterampilan/wawasan

mengenai perpajakannya dengan menumbuhkan motivasinya terlebih dahulu. Upaya penumbuhan motivasi ini dapat dilakukan oleh KPP dengan cara melakukan program penyegaran, in house training ataupun pemberian penghargaan kepada jurusita pajak yang berprestasi. Hal ini juga turut berpengaruh terhadap kemampuan berkomunikasi seorang jurusita pajak. Jurusita pajak akan mampu berkomunikasi dengan baik apabila

memiliki

keterampilan/wawasan

mengenai perpajakan yang lebih luas.

6. Pemberian keringanan berupa pembebasan denda kepada wajib pajak yang bersikap aktif terhadap pelaksanaan penagihan tertentu, dengan memberi kemudahan dan keringanan dalam pelunasan tunggakan.

7. Wajib pajak dapat mengajukan keberatan dan banding, juga diberikan kesempatan untuk mengangsur tunggakan pajaknya.

8. Dalam hal pendaftaran wajib pajak baru, perlu dilakukan penelitian lapangan agar alamat yang diberikan oleh wajib pajak dapat dibuktikan kebenarannya (tidak fiktif).

\section{KESIMPULAN DAN SARAN 4.1 Kesimpulan}

1. Keefektifan pencairan tunggakan pajak adalah tingkat keberhasilan atau ketepatan sasaran yang dicapai dari usaha melunasi utang pajak oleh wajib pajak/penanggung pajak dengan tujuan yang berhubungan dengan penyelenggaraan pemerintahan.

2. Kantor Pelayanan Pajak Pratama Medan Kota ialah salah satu unsur pelaksana kegiatan operasional pemberian pelayanan di lingkungan Direktorat Jenderal Pajak Kanwil Sumut I dan bertugas menghimpun 
penerimaan negara dari sektor pajak.

3. Salah satu tugas dari KPP Pratama Medan Kota ialah melaksanakan penagihan dengan melakukan pencairan tunggakan pajak untuk meningkatkan penerimaan pajak.

4. Tingkat keefektifan pencairan tunggakan pajak dari tahun 2010 sampai dengan tahun 2014 masih kurang efektif, dimana perbandingan realisasi tunggakan pajak dan total tunggakan pajak setiap tahun pada KPP Pratama Medan Kota adalah berbanding tegak lurus, yang realisasinya mengalami peningkatan tetapi total tunggakan pajaknya juga meningkat selama lima tahun terakhir, hal ini dikarenakan adanya upaya penggalian potensi penerimaan pajak (extraeffort).

5. Tingkat keefektifan penerimaan pajak dari tahun 2010 sampai dengan tahun 2014 efektif, dimana untuk tahun 2010 sampai 2012 realisasi penerimaan pajak telah mencapai target/rencana penerimaan pajak, dan untuk tahun 2013 sampai 2014 memperoleh jumlah realisasi yang masih mendukung dari target/rencana penerimaan pajak.

6. Hambatan-hambatan yang ditemukan dalam pelaksanaan penagihan pencairan tunggakan pajak dapat dilihat dari minimnya pengetahuan wajib pajak tentang peraturan perpajakan beserta rendahnya kesadaran wajib pajak akan kewajiban perpajakannya terbukti dengan penambahan tunggakan yang semakin meningkat, yang selanjutnya adalah dilihat dari kinerja fiskus dengan adanya penambahan tunggakan yang tidak diimbangi dengan pencairan tunggakannya.

\subsection{Saran}

\section{DAFTAR PUSTAKA}

Mardiasmo, 2011, "Perpajakan Edisi Revisi Tahun 2011", Andi, Yogyakarta

Rahardjo, Adisasmita, 2011, "Pengelolaan Pendapatan dan Anggaran Daerah", Graha Ilmu, Yogyakarta

Resmi, Siti, 2013,"Perpajakan Teori dan Kasus Edisi 7 Buku l', Salemba Empat, Jakarta

Sari, Diana, 2013, "Konsep Dasar Perpajakan”, Bandung

Sembiring, Jakaria dkk, 2014 "Pedoman Penyusunan Proposal Dan Tugas Akhir", Politeknik Unggul LP3M Medan, Medan

Soetopo, Hendayat, 2010, "Perilaku Organisasi Teori dan Praktek Pendidikan",

Rosda, Bandung

Undang-Undang No. 16 Tahun 2009, "Tentang Ketentuan Umum Dan Tata Cara Perpajakan" 